ARTICLE

\title{
Silica-copper catalyst interfaces enable carbon- carbon coupling towards ethylene electrosynthesis
}

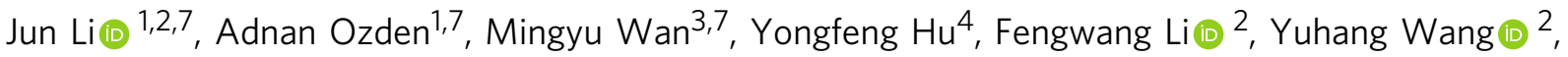

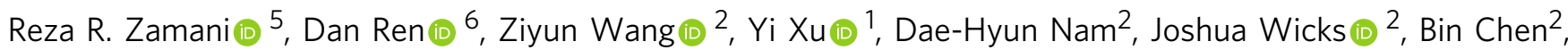

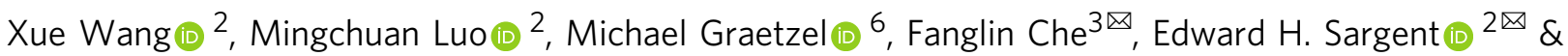
David Sinton (1) ${ }^{1 \times}$

Membrane electrode assembly (MEA) electrolyzers offer a means to scale up $\mathrm{CO}_{2}$-toethylene electroconversion using renewable electricity and close the anthropogenic carbon cycle. To date, excessive $\mathrm{CO}_{2}$ coverage at the catalyst surface with limited active sites in MEA systems interferes with the carbon-carbon coupling reaction, diminishing ethylene production. With the aid of density functional theory calculations and spectroscopic analysis, here we report an oxide modulation strategy in which we introduce silica on $\mathrm{Cu}$ to create active $\mathrm{Cu}-\mathrm{SiO}_{x}$ interface sites, decreasing the formation energies of $\mathrm{OCOH}^{*}$ and $\mathrm{OCCOH}^{\star}-$ key intermediates along the pathway to ethylene formation. We then synthesize the $\mathrm{Cu}-\mathrm{SiO}_{x}$ catalysts using one-pot coprecipitation and integrate the catalyst in a MEA electrolyzer. By tuning the $\mathrm{CO}_{2}$ concentration, the $\mathrm{Cu}-\mathrm{SiO}_{x}$ catalyst based MEA electrolyzer shows high ethylene Faradaic efficiencies of up to $65 \%$ at high ethylene current densities of up to $215 \mathrm{~mA} \mathrm{~cm}^{-2}$; and features sustained operation over $50 \mathrm{~h}$.

\footnotetext{
${ }^{1}$ Department of Mechanical and Industrial Engineering, University of Toronto, Toronto, ON, Canada. ${ }^{2}$ Department of Electrical and Computer Engineering, University of Toronto, Toronto, ON, Canada. ${ }^{3}$ Chemical Engineering, University of Massachusetts Lowell, Lowell, MA, USA. ${ }^{4}$ Canadian Light Source Inc., University of Saskatchewan, Saskatoon, SK, Canada. ${ }^{5}$ Interdisciplinary Center for Electron Microscopy, École Polytechnique Fédérale de Lausanne,

Lausanne, Switzerland. ${ }^{6}$ Laboratory of Photonics and Interfaces, Institute of Chemical Sciences and Engineering, École Polytechnique Fédérale de Lausanne, Lausanne, Switzerland. ${ }^{7}$ These authors contributed equally: Jun Li, Adnan Ozden, Mingyu Wan. ${ }^{凶}$ email: fanglin_che@uml.edu; ted.sargent@utoronto.ca; sinton@mie.utoronto.ca
} 
C $\mathrm{O}_{2}$ electroreduction $\left(\mathrm{CO}_{2} \mathrm{RR}\right)$, powered by renewable electricity, represents a carbon-neutral pathway for the production of value-added hydrocarbons and alcohols ${ }^{1-3}$. Ethylene, a precursor in the chemical industry, has been prioritized as a target in $\mathrm{CO}_{2} \mathrm{RR}$ owing to its annual global production of 140 million metric tons and a market value of 182 billion $\mathrm{USD}^{4}$. However, the present-day performance of $\mathrm{CO}_{2}$-to-ethylene electrocatalysis-in terms of efficiency, production rate, and stability-is insufficient to compete with ethylene production from fossil sources ${ }^{4,5}$.

Gas diffusion electrodes (GDEs) embedded in alkaline flow cell electrolyzers have enabled selective $\mathrm{CO}_{2}$-to-ethylene conversion at industrial-level production rates ${ }^{6,7}$. However, $\mathrm{CO}_{2}$ utilization remains low due to the rapid reaction of $\mathrm{CO}_{2}$ molecules and hydroxide ions in these systems ${ }^{2}$. In addition, direct contact between GDE and aqueous electrolyte leads to electrode flooding and catalyst deactivation ${ }^{8,9}$

The membrane electrode assembly (MEA) electrolyzer, with a direct cathode:membrane:anode contact, offers a platform that is more stable than alkaline flow cell electrolyzers ${ }^{10-12}$. A low cell resistance of zero-gap MEA electrolyzers also enables the use of bicarbonate or carbonate electrolyte without sacrificing the $\mathrm{CO}_{2} \mathrm{RR}$ efficiency ${ }^{13,14}$. Copper $(\mathrm{Cu})$ has an adequate activation energy of $\mathrm{CO}_{2}$ and shows near-optimal $\mathrm{CO}$ binding, a key to producing ethylene ${ }^{15,16}$. However, the Faradaic efficiency (FE) toward ethylene reported on bare $\mathrm{Cu}$ catalysts in MEA systems is limited to $<50 \%{ }^{10}$.

Excessive local $\mathrm{CO}_{2}$ at the $\mathrm{Cu}$ catalysts surface, a result of fast mass transport of $\mathrm{CO}_{2}$ in flowing gas systems, and a lack of active sites diminishes ethylene formation due to the strong lateral interaction between adsorbed $\mathrm{CO}_{2}$ and $\mathrm{CO}_{2} \mathrm{RR}$ intermediates ${ }^{17}$. Introducing an element through doping ${ }^{18,19}$, alloying ${ }^{20,21}$, or molecule-modification ${ }^{22,23}$, offers a means to modify the structure of metallic $\mathrm{Cu}$ catalysts and has improved the $\mathrm{FE}_{\text {ethylene }}$ to an impressive $64 \%$ in an MEA electrolyzer ${ }^{22}$, but with ethylene productivity $<100 \mathrm{~mA} \mathrm{~cm}^{-2}$.

A recent techno-economic analysis indicates that practical and economic ethylene production requires productivities greater than $200 \mathrm{~mA} \mathrm{~cm}^{-2}$ (ref. ${ }^{2}$ ). This indicates the need for catalysts that achieve both high selectivity $(>60 \%)$ and high activity $\left(>300 \mathrm{~mA} \mathrm{~cm}^{-2}\right.$ ), likely through designing a catalyst capable of accelerating $\mathrm{CO}_{2}$ activation and enabling efficient and continuous electron/proton transfer steps with strict control over the key reaction step-the carbon-carbon $(\mathrm{C}-\mathrm{C})$ coupling 3,24 .

The formation of $\mathrm{OCCOH}^{*}$ intermediate from $\mathrm{C}-\mathrm{C}$ coupling has been identified as a key step toward ethylene production ${ }^{25}$. Low-index and stepped $\mathrm{Cu}$ facets reduce the formation energy of the $\mathrm{OCCOH}^{*}$ intermediate, due to efficient charge transfer between surface step sites and $\mathrm{CO}_{2} \mathrm{RR}$ intermediates ${ }^{15}$. However, under-coordinated step sites are rare in bulk $\mathrm{Cu}$ and less stable compared to $\mathrm{Cu}(111)$.

Herein, we report an oxide modulation strategy based on silicaa modifier oxide that has strong affinities to $\mathrm{Cu}$ and $\mathrm{O}$ - to create abundant $\mathrm{Cu}-\mathrm{SiO}_{x}$ interface stepped sites, assisting $\mathrm{CO}_{2}$ activation and the formation of the $\mathrm{OCCOH}^{*}$ intermediate. We first assess the role of silica in affecting $\mathrm{CO}_{2} \mathrm{RR}$ on $\mathrm{Cu}$ using density functional theory (DFT) calculations. We find that a silica addition on a $\mathrm{Cu}$ surface significantly lowers the formation energies of the key intermediates $\mathrm{OCOH}^{*}$ and $\mathrm{OCCOH}^{*}$ at the $\mathrm{Cu}-\mathrm{SiO}_{x}$ interface sites via forming strong $\mathrm{Si}-\mathrm{O}$ or $\mathrm{Si}-\mathrm{C}$ bonds, and leads to a cascade of coupled electron/proton transfer reactions that enhance $\mathrm{CO}_{2}$-toethylene conversion. We then synthesize a $\mathrm{Cu}-\mathrm{SiO}_{x}$ catalyst using one-pot coprecipitation. Through microscopy and spectroscopy, we find that $\mathrm{Si}$ species uniformly distribute at the $\mathrm{Cu}$ surface, forming abundant $\mathrm{Cu}-\mathrm{SiO}_{x}$ interfaces to catalyze $\mathrm{CO}_{2}$. We integrate the $\mathrm{Cu}-$ $\mathrm{SiO}_{x}$ catalyst in a MEA electrolyzer and achieve a $\mathrm{FE}$ of $65 \%$ at a current density of $215 \mathrm{~mA} \mathrm{~cm}^{-2}$ for $\mathrm{CO}_{2}$-to-ethylene conversion, two-fold greater ethylene productivity in MEA compared to literature benchmarks. We further assess the performance of the $\mathrm{Cu}-\mathrm{SiO}_{x}$ catalyst in dilute $\mathrm{CO}_{2}$ streams, with the aim of directly converting flue gases. We demonstrate stable $\mathrm{CO}_{2}$-to-ethylene conversion with FEs of $>60 \%$ at current densities in the range of $120-300 \mathrm{~mA} \mathrm{~cm}^{-2}$ across a wide window of $\mathrm{CO}_{2}$ concentrations (10-100\%) and for a run time over $50 \mathrm{~h}$.

\section{Results}

Density functional theory calculations. Excessive local $\mathrm{CO}_{2}$ at the $\mathrm{Cu}$ catalyst layer interferes with the adsorption of $\mathrm{CO}_{2} \mathrm{RR}$ intermediates, diminishing the $\mathrm{C}-\mathrm{C}$ coupling at the $\mathrm{Cu}$ surface with limited active sites for ethylene production ${ }^{17}$. In light of this finding, we sought to identify, with the aid of DFT calculations, a catalyst candidate having abundant active sites to enable $\mathrm{CO}_{2}$ activation in MEA systems and facilitate the $\mathrm{C}-\mathrm{C}$ coupling toward ethylene formation.

Si-based materials have been applied to facilitate $\mathrm{CO}_{2}$ hydrogenation; however, $\mathrm{Si}$ itself has been found to react irreversibly with $\mathrm{CO}_{2}$ by forming surface silanols $(\mathrm{Si}-\mathrm{OH})$ and siloxane ( $\mathrm{Si}-\mathrm{O}-\mathrm{Si})$ groups ${ }^{26,27}$. We instead considered silica, because it is more stable and is an efficient adsorbent material to capture $\mathrm{CO}_{2}^{28}$, besides it shows strong affinities to $\mathrm{Cu}^{29}$. We thus hypothesized that a $\mathrm{Cu}$ surface modified with silica could offer a new approach to $\mathrm{CO}_{2} \mathrm{RR}$. Using DFT calculations we first introduced silica clusters at the $\mathrm{Cu}$ surface to establish a $\mathrm{Cu}-\mathrm{SiO}_{x}$ step surface configuration (Supplementary Fig. 1) and calculated the energetics of forming possible $\mathrm{Cu}-\mathrm{SiO}_{x}$ catalysts with various silica loadings (Supplementary Figs. 2-4 and Supplementary Table 1). We found a slight increase of the Si oxidation state from +1.9 to +2.4 , as the silica concentration increases from $1 / 16$ to $3 /$ 16 monolayer (ML) (i.e., 1.6-4.7\%) (Fig. 1a).

We then investigated the first proton/electron transfer to $\mathrm{CO}_{2}$ $\left(\mathrm{CO}_{2 \text { (gas) }}+\mathrm{H}^{+}+\mathrm{e}^{-} \leftrightarrow \mathrm{OCOH}^{*}\right)$ with and without silica, a key step for $\mathrm{CO}_{2}$ activation (Supplementary Figs. 5-7). DFT results show that the $\mathrm{Cu}-\mathrm{SiO}_{x}$ catalyst significantly decreases the formation energy of $\mathrm{OCOH}^{*}$ up to $\sim 0.7 \mathrm{eV}$ compared to the bare $\mathrm{Cu}$ catalyst, due to the strong electronic interaction between $\mathrm{Si}$ and $\mathrm{O} / \mathrm{C}$ in the $\mathrm{OCOH}^{*}$ intermediate (vide infra), indicating that a silica addition promises efficient $\mathrm{CO}_{2}$ activation.

We further calculated the formation energy of $\mathrm{OCCOH}^{*}$ through the coupling of $\mathrm{CO}^{*}$ and $\mathrm{COH}^{*}$ (Fig. 1b), a key descriptor to enhance $\mathrm{C}_{2}$ production from $\mathrm{CO}_{2} \mathrm{RR}^{15,25}$. We examined the co-adsorption of $\mathrm{CO}^{*}$ and $\mathrm{COH}^{*}$ over the energetically favorable and metastable $\mathrm{Cu}-\mathrm{SiO}_{x}$ models (Supplementary Figs. 2-4) and found that all $\mathrm{Cu}$ catalysts, with and without silica, exhibit similar values (Supplementary Figs. 8-12), suggesting that the silica addition does not change the adsorption properties of $\mathrm{CO}^{*}$ or $\mathrm{COH}^{*}$. However, various $\mathrm{Cu}$ $\mathrm{SiO}_{x}$ catalysts show a much higher adsorption energy of up to $\sim 1.2 \mathrm{eV}$ for the as-formed $\mathrm{OCCOH}^{*}$ intermediate than the bare $\mathrm{Cu}$ catalyst (Supplementary Figs. 13-15). As a result, for the $\mathrm{Cu}-\mathrm{SiO}_{x}$ catalysts with equilibrium geometries, we found that increasing the silica loading up to $3.1 \%$ decreases the formation energy of $\mathrm{OCCOH}^{*}$ by $\sim 1.1 \mathrm{eV}$ (Fig. 1b). A further increase of the silica concentration to $4.7 \%$ disfavors $\mathrm{OCCOH}^{*}$ formation, showing reaction energy similar to that of bare $\mathrm{Cu}$. This volcano-shaped dependence of the $\mathrm{OCCOH}^{*}$ formation energy based on the silica loading suggests that a proper loading of silica on $\mathrm{Cu}$ could provide a means to construct active interface sites for improving $\mathrm{C}_{2}$.

To determine the role of silica in enhancing the $\mathrm{OCCOH}^{*}$ adsorption at the $\mathrm{Cu}-\mathrm{SiO}_{x}$ step surface, we generated a differential charge density between $\mathrm{OCCOH}^{*}$ and $\mathrm{Cu}-\mathrm{SiO}_{x}$ (at a silica 

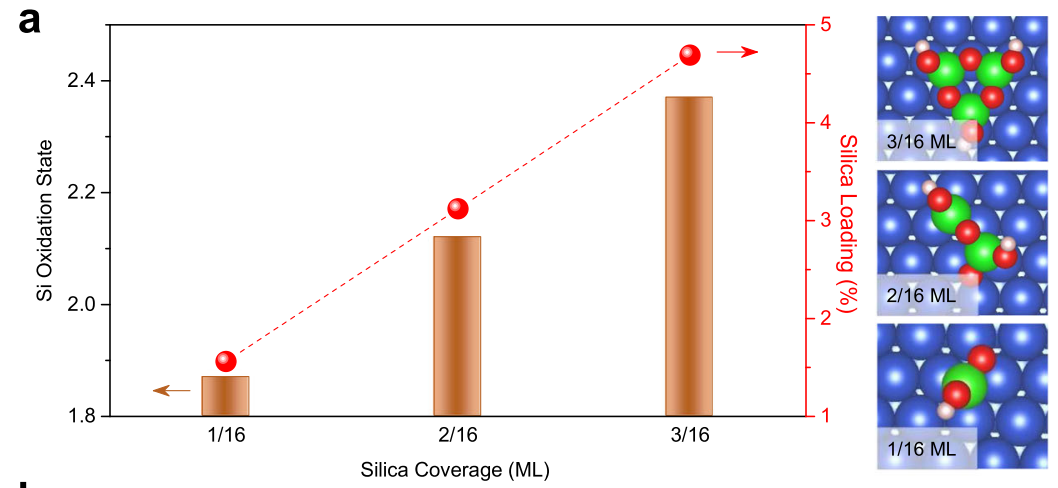

C

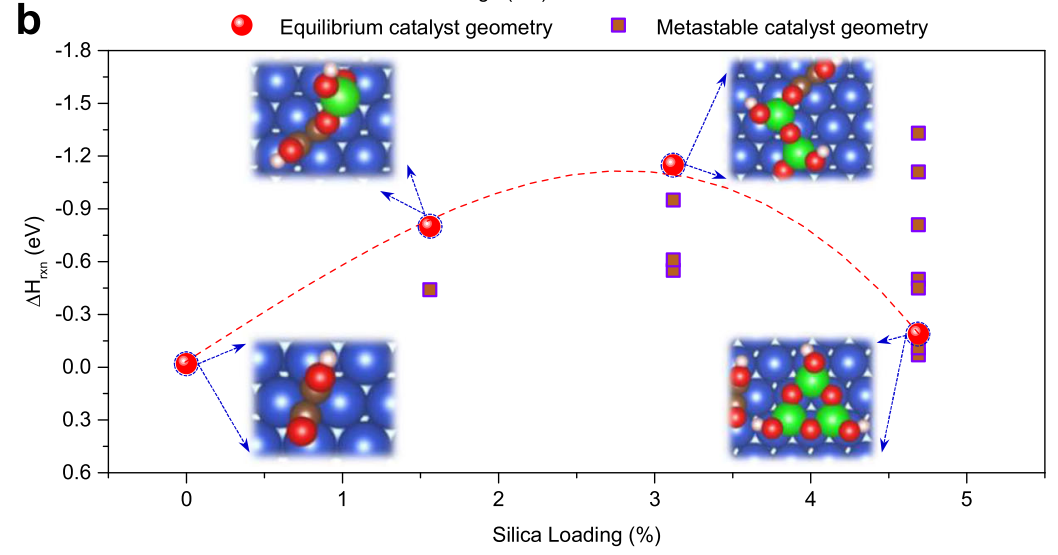

Si-C bond

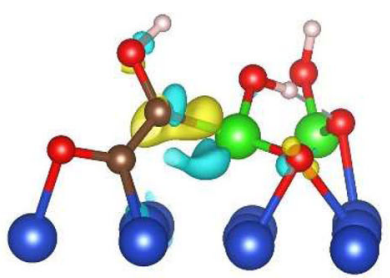

Si-O bond

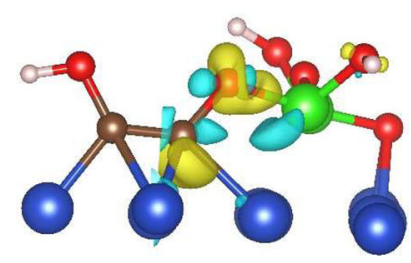

Fig. 1 DFT calculations. a The oxidation state of $\mathrm{Si}$ and silica loading as a function of silica coverage over $\mathrm{Cu}(111)$ at the energetically favorable catalyst geometries. b The formation energy $\left(\triangle H_{r x n}\right)$ of $\mathrm{OCCOH}^{*}\left(\mathrm{CO}^{*}+\mathrm{COH}^{*} \rightarrow \mathrm{OCCOH}^{*}\right)$ over the pure $\mathrm{Cu}(111)$ and possible $\mathrm{Cu}-\mathrm{SiO}_{x}$ catalysts, including equilibrium (sphere) and metastable (square) catalyst geometries; A volcano-like plot is achieved for the formation energy of $\mathrm{OCCOH}^{\star}$ over the equilibrium $\mathrm{Cu}-\mathrm{SiO}_{x}$ catalyst geometries. c Differential charge density plots show the $3.1 \%$ silica-loaded $\mathrm{Cu}_{-} \mathrm{SiO}_{x}$ step surface can stabilize OCCOH${ }^{\star}$ adsorption by creating either $\mathrm{Si}-\mathrm{C}$ or $\mathrm{Si}-\mathrm{O}$ bonds and lower the formation energy of the $\mathrm{OCCOH}^{*}$ intermediate. The iso-surface level of the differential charge densities is $0.012 \mathrm{e} / \mathrm{bohr}^{3}$. The yellow or blue areas represent a gain or loss of electrons. Color-coded atoms represent Cu (blue), Si (green), $\mathrm{O}$ (red), $\mathrm{C}$ (brown), and $\mathrm{H}$ (pink).

loading of $3.1 \%$, Fig. 1c) in which silica loses electrons (blue) and the adsorbed $\mathrm{OCCOH}^{*}$ gains electrons (yellow). For Si-C bond formation, the $\mathrm{C}^{1}$ atom of the $\mathrm{O}=\mathrm{C}^{1}-\mathrm{C}^{2}-\mathrm{OH}^{*}$ intermediate has one electron in a $s p^{2}$ orbital that bonds to $\mathrm{Cu}$, while the $\mathrm{C}^{2}$ atom makes more of a carbene and tends to bond more strongly to $\mathrm{Si}$ than $\mathrm{Cu}$, increasing the adsorption energy of $\mathrm{OCCOH}^{*}$ and thus decreasing the formation energy of $\mathrm{OCCOH}^{*}$ up to $0.6 \mathrm{eV}$ (Supplementary Figs. 16 and 17). A much stronger adsorption of $\mathrm{OCCOH}^{*}$ over the $\mathrm{Cu}-\mathrm{SiO}_{x}$ catalyst is due to the formation of the $\mathrm{Si}-\mathrm{O}$ bond between $\mathrm{O}^{\delta-}$ of the $\mathrm{OCCOH}^{*}$ intermediate and silica at the $\mathrm{Cu}-\mathrm{SiO}_{x}$ step site, leading to an enhancement in the adsorption energy of $\mathrm{OCCOH}^{*}$ and thus lowering the formation energy of $\mathrm{OCCOH}^{*}$ up to $\sim 1.2 \mathrm{eV}$ (Supplementary Figs. 18 and 19).

When the silica loading is increased to $4.7 \%$, the silica component energetically favors the formation a $\mathrm{Si}-\mathrm{O}-\mathrm{Si}$ layer, which fails to form $\mathrm{Si}-\mathrm{C}$ or $\mathrm{Si}-\mathrm{O}$ bond with the $\mathrm{OCOH}^{*}$ and $\mathrm{OCCOH}^{*}$ intermediates, due to the lack of unpaired electrons in $\mathrm{Si}$. As a result, the $\mathrm{Cu}-\mathrm{SiO}_{x}$ catalyst shares similar adsorption energies of both the $\mathrm{OCOH}^{*}$ and $\mathrm{OCCOH}^{*}$ intermediates to the bare Cu catalyst (Supplementary Figs. 7 and 15). Collectively, the DFT calculations predict that introducing a silica addition at a loading of $3 \%$ could establish a stable $\mathrm{Cu}-\mathrm{SiO}_{x}$ interface that lowers the formation energies of $\mathrm{OCOH}^{*}$ and $\mathrm{OCCOH}^{*}$, and increases the efficiency of $\mathrm{CO}_{2}$-to-ethylene conversion.

Materials synthesis and characterization. We pursued a one-pot coprecipitation method to prepare the silica-modified $\mathrm{Cu}$ catalysts, dissolving silicon tetrachloride and copper chloride in ethanol. A $\mathrm{Cu}-\mathrm{SiO}_{x}$ catalyst was then coprecipitated by adding $\mathrm{NaBH}_{4}$ directly into the precursor solution. We tuned the silica loading in the $\mathrm{Cu}$ structure from 0 to $5 \%$ (denoted $\mathrm{Cu}-\mathrm{SiO}_{x}-\mathrm{M}$, where $\mathrm{M}$ represents the silica loading percentage) by varying the $\mathrm{Si}: \mathrm{Cu}$ atomic ratio in the precursor solution. The silica loading was quantified by inductively coupled plasma optical emission spectrometry (ICP-OES, Supplementary Table 2).

Transmission electron microscopy and scanning electron microscopy images show nanoparticles in an aggregated form and a mean size of $\sim 50 \mathrm{~nm}$. The $\mathrm{Cu}$ morphology is unchanged with silica loading (Fig. 2a and Supplementary Fig. 20). The catalysts with/without silica loading lead to similar $\mathrm{Cu}$ patterns, seen in X-ray powder diffraction (XRD) measurements (Supplementary Fig. 21). We examined and compared the structure of the $\mathrm{Cu}-\mathrm{SiO}_{x}$ catalyst before and after $\mathrm{CO}_{2} \mathrm{RR}$ using high-angle annular dark-field scanning transmission electron microscopy (HAADF-STEM) and energy-dispersive X-ray (EDX) mapping. We found that the Si species are evenly distributed on the $\mathrm{Cu}$ catalyst surface, and that the structure of $\mathrm{Si}$ species remains intact before and after the reaction, showing an oxidation state of +2 as revealed by X-ray photoelectron spectroscopy (XPS, Fig. $2 \mathrm{~b}-\mathrm{f}$ and Supplementary Figs. 22-27) ${ }^{30}$. Using HAADF-STEM and XPS, we also characterized the $\mathrm{Cu}-\mathrm{SiO}_{x}$ catalysts with silica loadings of 2.5\% (Figs. 2) and 5\% (Supplementary Figs. 28-31), and found similar silica structures in both samples and detected no aggregation of silica, suggesting that silica clusters are uniformly distributed on the $\mathrm{Cu}$ surface. We note that characterizations of catalyst morphology were performed under ex-situ conditions. 

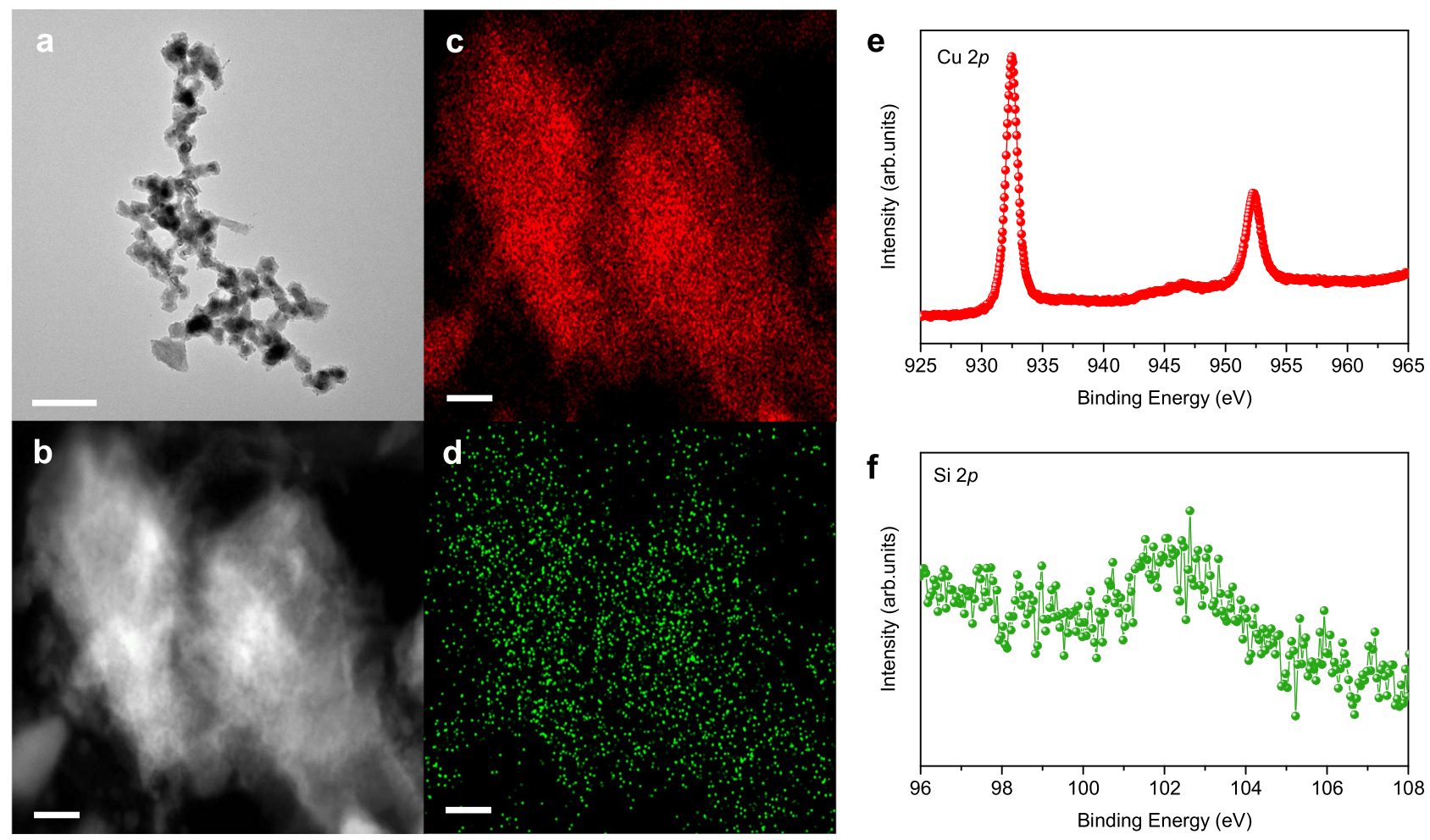

Fig. $\mathbf{2}$ Characterization of $\mathbf{2 . 5 \%}$ silica-loaded Cu catalyst. a-d TEM image (a), HAADF-STEM image (b), and EDX elemental mapping of Cu (c) and Si (d), The scale bars are $200 \mathrm{~nm}$ in a and $20 \mathrm{~nm}$ in b-d. e, f XPS spectra of $\mathrm{Cu} 2 p$ (e) and Si $2 p$ (f). All measurements were performed upon completion of $\mathrm{CO}_{2} \mathrm{RR}$ at a full-cell potential of $-4.1 \mathrm{~V}$ in $0.1 \mathrm{M} \mathrm{KHCO}_{3}$.

Although the extent of any catalyst reconstruction due to the potential removal after $\mathrm{CO}_{2} \mathrm{RR}$ is not expected to be major, the development of in-situ TEM capabilities will be useful to assess the impact of potential removal on catalyst reconstruction, if any.

Electrochemical $\mathrm{CO}_{2}$ conversion. We evaluated the $\mathrm{CO}_{2} \mathrm{RR}$ performance of the $\mathrm{Cu}-\mathrm{SiO}_{x}$ catalysts in a $5 \mathrm{~cm}^{2} \mathrm{MEA}$ electrolyzer (Fig. 3a), in which ethylene was produced according to the overall reaction of $2 \mathrm{CO}_{2}+2 \mathrm{H}_{2} \mathrm{O} \rightarrow \mathrm{C}_{2} \mathrm{H}_{4}+3 \mathrm{O}_{2}\left(\mathrm{E}^{\circ}=1.15 \mathrm{~V}\right)$. In this system, a humidified $\mathrm{CO}_{2}$ feedstock was fed through the cathode without the presence of catholyte, and the $\mathrm{Cu}-\mathrm{SiO}_{x}$ catalyst of interest was sandwiched between a PTFE gas diffusion layer and an anion exchange membrane (AEM) to enable sufficient $\mathrm{CO}_{2}$ reactants and abundant reaction interfaces, whereas $0.1 \mathrm{M} \mathrm{KHCO}_{3}$ aqueous solution was interfaced with anode catalysts $\left(\mathrm{IrO}_{2}\right.$ coated onto a Ti mesh) to initiate the oxygen evolution reaction (OER). The ohmic loss was minimized, due to the absence of catholyte and direct contact between the catalyst and the AEM.

In a silica loading range of $0-5 \%$ on $\mathrm{Cu}$, we found a strong correlation between the silica loading and ethylene formation (Fig. 3b and Supplementary Fig. 32). We observed a gradual increase in $\mathrm{FE}_{\text {ethylene }}$ and a decrease in $\mathrm{FE}_{\mathrm{CO}}$ with increasing silica loading up to $2.5 \%$, whereas we noted a decrease in $\mathrm{FE}_{\text {ethylene }}$ with a further increase in the silica loading from 2.5 to $5 \%$, accompanying an enhancement in $\mathrm{FE}_{\mathrm{CO}}$. The volcano relation between $\mathrm{FE}_{\text {ethylene }}$ and the silica loading agrees well with the volcano correlation between the formation energy of $\mathrm{OCCOH}^{*}$ and the silica loading ranging from 0 to $5 \%$ (equivalent to a silica coverage of $0-3 / 16 \mathrm{ML}$ ) predicted by DFT calculations (Fig. 1b). We observed that the total and hydrogen current densities do not vary significantly in the range of silica loadings tested (Supplementary Fig. 33), implying similar physical availability (i.e., mass transport) of $\mathrm{CO}_{2}$.
We then focused on the $2.5 \%$ silica-loaded $\mathrm{Cu}$ catalyst $(\mathrm{Cu}$ $\left.\mathrm{SiO}_{x}-2.5\right)$ and observed that $\mathrm{FE}_{\text {ethylene }}$ of the $\mathrm{Cu}-\mathrm{SiO}_{x}-2.5$ catalyst outperforms that of the bare $\mathrm{Cu}$ catalyst across the full-cell potential range of $-3.0 \mathrm{~V} \sim-4.25 \mathrm{~V}$ (Fig. 3c). The $\mathrm{Cu}-\mathrm{SiO}_{x}-2.5$ catalyst reaches a peak $\mathrm{FE}_{\text {ethylene }}$ of $65 \%$ at a cell potential of $-4.1 \mathrm{~V}$, whereas a peak $\mathrm{FE}_{\text {ethylene }}$ of $50 \%$ of the bare Cu catalyst is achieved at $-4.2 \mathrm{~V}$. The ethylene current densities of the $\mathrm{Cu}-$ $\mathrm{SiO}_{x}-2.5$ and bare $\mathrm{Cu}$ catalysts increase with increasing cell potential in the negative direction and peak at 215 and $160 \mathrm{~mA}$ $\mathrm{cm}^{-2}$ at cell potentials of -4.2 and $-4.25 \mathrm{~V}$, respectively (Fig. $3 \mathrm{~d}$ ). This performance exceeds prior MEA reports with a two-fold enhancement in ethylene current density (Supplementary Table 3). The $\mathrm{Cu}-\mathrm{SiO}_{x}-2.5$ catalyst shows considerably lower $\mathrm{FE}_{\mathrm{CO}}$ and $\mathrm{CO}$ current density than the bare $\mathrm{Cu}$ catalyst (Fig. 3e and Supplementary Fig. 34), in agreement with our DFT results that the silica addition facilitates the $\mathrm{C}-\mathrm{C}$ coupling reaction (Fig. 1). A further analysis of liquid products (Fig. 3f), using ${ }^{1} \mathrm{H}$ nuclear magnetic resonance ( ${ }^{1} \mathrm{H}$-NMR) spectroscopy, reveals that the $\mathrm{Cu}-\mathrm{SiO}_{x}-2.5$ catalyst also yields lower FEs toward multicarbon oxygenate products (i.e., acetate, ethanol, and 1-propanol) than the bare $\mathrm{Cu}$ catalyst.

Investigating the $\mathrm{Cu}-\mathrm{SiO}_{x}$ interaction. To understand the role of silica in promoting ethylene production at the $\mathrm{Cu}-\mathrm{SiO}_{x}$ catalyst, we performed in-situ Raman spectroscopy (Supplementary Table 4). At a range of applied cell potentials from -1.5 to $-2.0 \mathrm{~V}$ (Fig. 4a, b), we observed one band at $280 \mathrm{~cm}^{-1}$ on the bare $\mathrm{Cu}$ electrode starting from $-1.8 \mathrm{~V}$, attributable to the $\mathrm{Cu}-\mathrm{CO}$ frustrated rotation at metallic $\mathrm{Cu}$ surface ${ }^{31,32}$. On the $\mathrm{Cu}-\mathrm{SiO}_{x}-2.5$ electrode, the same band emerged at the cell potential of $-1.8 \mathrm{~V}$, together with the emergence of a new band at $365 \mathrm{~cm}^{-1}$. This additional band is due to the $\mathrm{Cu}-\mathrm{O}$ stretch at the metallic $\mathrm{Cu}$ surface, indicating that a silica addition increases $\mathrm{CO}$ coverage at 
a
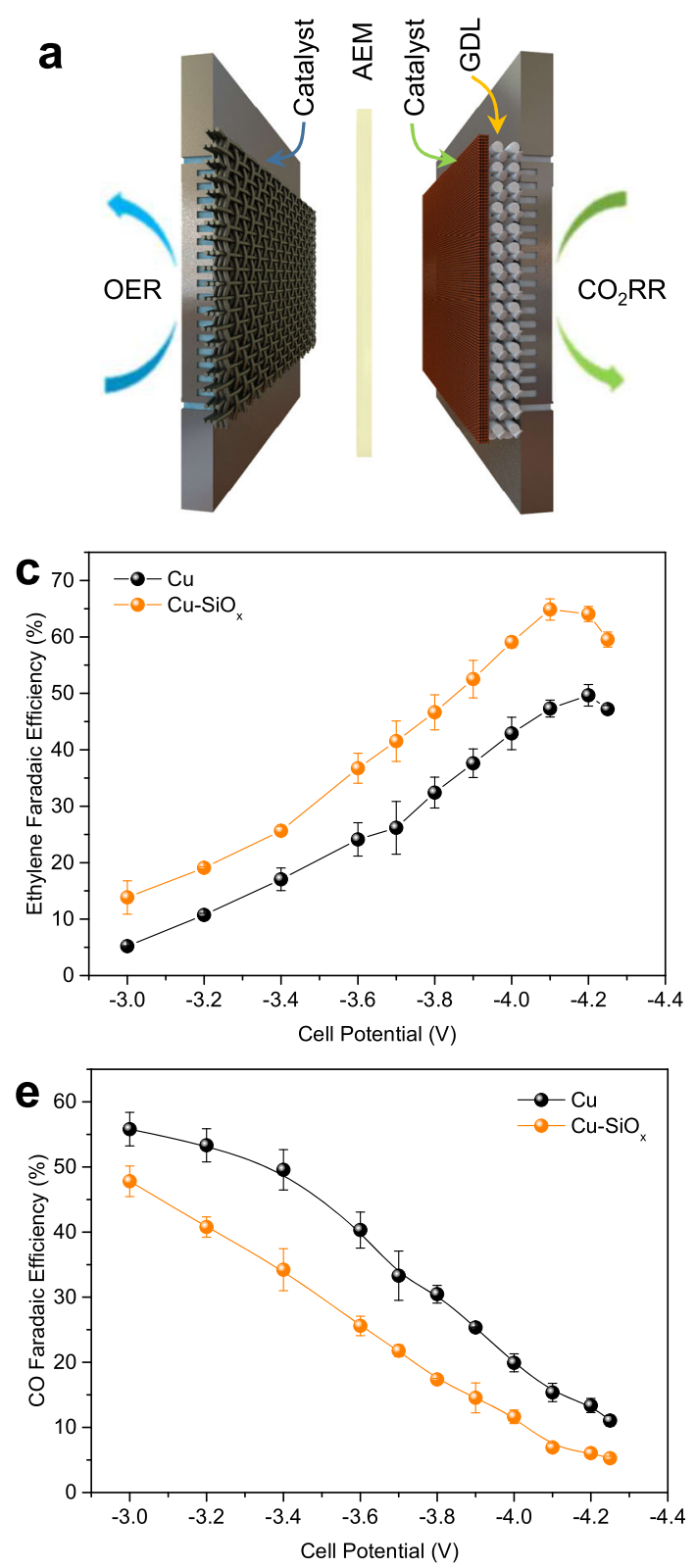

b
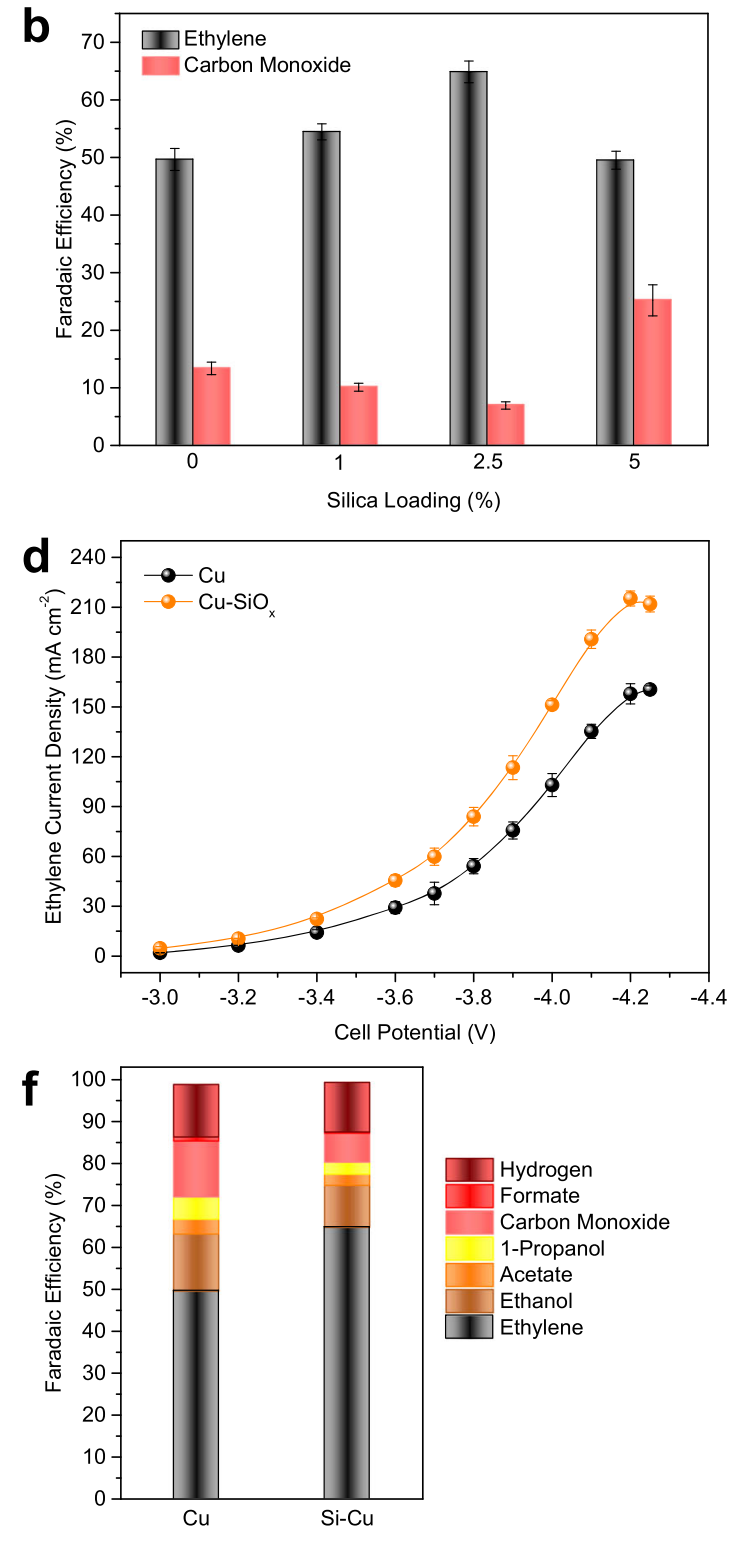

Fig. $3 \mathbf{C O}_{2}$ RR performance of different $\mathbf{C u}-\mathrm{SiO}_{\mathbf{x}}$ catalysts in a MEA electrolyzer with $\mathbf{0 . 1} \mathbf{M} \mathbf{~} \mathbf{K} \mathbf{H C O}_{3}$ anolyte. a Schematic illustration of the MEA cell (OER: oxygen evolution reaction, $\mathrm{AEM}$ : anion exchange membrane, GDL: gas diffusion layer). $\mathbf{b}$ The peak $\mathrm{FE}_{\text {ethylene }}$ and corresponding $\mathrm{FE}_{\mathrm{CO}}$ of the bare $\mathrm{Cu}$ and various $\mathrm{Cu}-\mathrm{SiO}_{x}$ catalysts. c-e Comparison of $\mathrm{FE}_{\text {ethylene }}$ (c), ethylene current density (d), and $\mathrm{FE}_{\mathrm{CO}}(\mathbf{e})$, respectively, between the $2.5 \%$ silica-loaded $\mathrm{Cu}$ and bare $\mathrm{Cu}$ catalysts. $\mathbf{f}$ The peak $\mathrm{FE}_{\text {ethylene }}$ and related FEs of the other products (i.e., ethanol, acetate, 1-propanol, $\mathrm{CO}$, formate, and hydrogen) of the $2.5 \%$ silica-loaded $\mathrm{Cu}$ and bare $\mathrm{Cu}$ catalysts. Error bars are means \pm SD $(n=3$ replicates).

the $\mathrm{Cu}$ surface ${ }^{32}$. In addition, we also observed a strong band at $530 \mathrm{~cm}^{-1}$ on the $\mathrm{Cu}-\mathrm{SiO}_{x}-2.5$ electrode throughout the cell potentials applied, which we attribute to the presence of $\mathrm{Cu}^{+}$ promoted by the $\mathrm{Cu}-\mathrm{O}-\mathrm{Si}$ interaction ${ }^{31}$.

To further assess the role of silica, we carried out in-situ Raman measurements on the $\mathrm{Cu}-\mathrm{SiO}_{x}-1$ and $\mathrm{Cu}-\mathrm{SiO}_{x}-5$ electrodes (Supplementary Fig. 35). While we observed the stable $\mathrm{Cu}-\mathrm{O}-\mathrm{Si}$ $\mathrm{i}$ band at $530 \mathrm{~cm}^{-1}$ in both cases throughout the cell potentials applied, the $\mathrm{Cu}-\mathrm{O}$ stretch band at $365 \mathrm{~cm}^{-1}$ emerged at a cell potential of $-2.0 \mathrm{~V}$ on $\mathrm{Cu}-\mathrm{SiO}_{x}-1$ and $-2.2 \mathrm{~V}$ on $\mathrm{Cu}-\mathrm{SiO}_{x}-5$. This shift in onset potential of the $365 \mathrm{~cm}^{-1}$ band indicates the tuning of $\mathrm{CO}$ content on $\mathrm{Cu}$ in response to silica loading. The $\mathrm{Cu}-\mathrm{SiO}_{x}-$ 2.5 catalyst shows the lowest onset potential of $-1.8 \mathrm{~V}$, suggesting the highest $\mathrm{CO}$ concentration at the $\mathrm{Cu}-\mathrm{SiO}_{x}-2.5$ catalyst surface during $\mathrm{CO}_{2} \mathrm{RR}$. This finding is consistent with our DFT predictions of the formation energy of $\mathrm{OCOH}^{*}$ - an intermediate in $\mathrm{CO}_{2}$-to- $\mathrm{CO}$ conversion-at the $\mathrm{Cu}-\mathrm{SiO}_{x}$ interface (Supplementary Figs. 5-7). The $\mathrm{Cu}-\mathrm{SiO}_{x}$ catalyst with optimal $\mathrm{CO}$ coverage at a silica loading of $2.5 \%$ accelerates the $\mathrm{C}-\mathrm{C}$ coupling by lowering the formation energy of $\mathrm{OCCOH}^{*}$ at the $\mathrm{Cu}-\mathrm{SiO}_{x}$ interface, facilitating the formation of ethylene (Fig. 1b) ${ }^{33}$.

To reveal the electronic interaction between $\mathrm{Cu}$ and silica, we conducted X-ray absorption spectroscopy (XAS) measurements at the $\mathrm{Cu} \mathrm{K}$ - and $\mathrm{Si}$ K-edges of the $\mathrm{Cu}-\mathrm{SiO}_{x}$ catalysts. In-situ Xray absorption near-edge structure (XANES) at the $\mathrm{Cu}$ K-edge shows the metallic nature of $\mathrm{Cu}$ active sites, corroborated by the extended X-ray absorption fine structure (EXAFS, Supplementary Fig. 36a-c). Although the presence of $\mathrm{Cu}^{+}$from the $\mathrm{Cu}-\mathrm{O}-\mathrm{Si}$ interaction is evidenced by in-situ Raman analysis, the $\mathrm{Cu} \mathrm{K}$-edge XAS recorded in fluorescence yield probes further into the bulk 

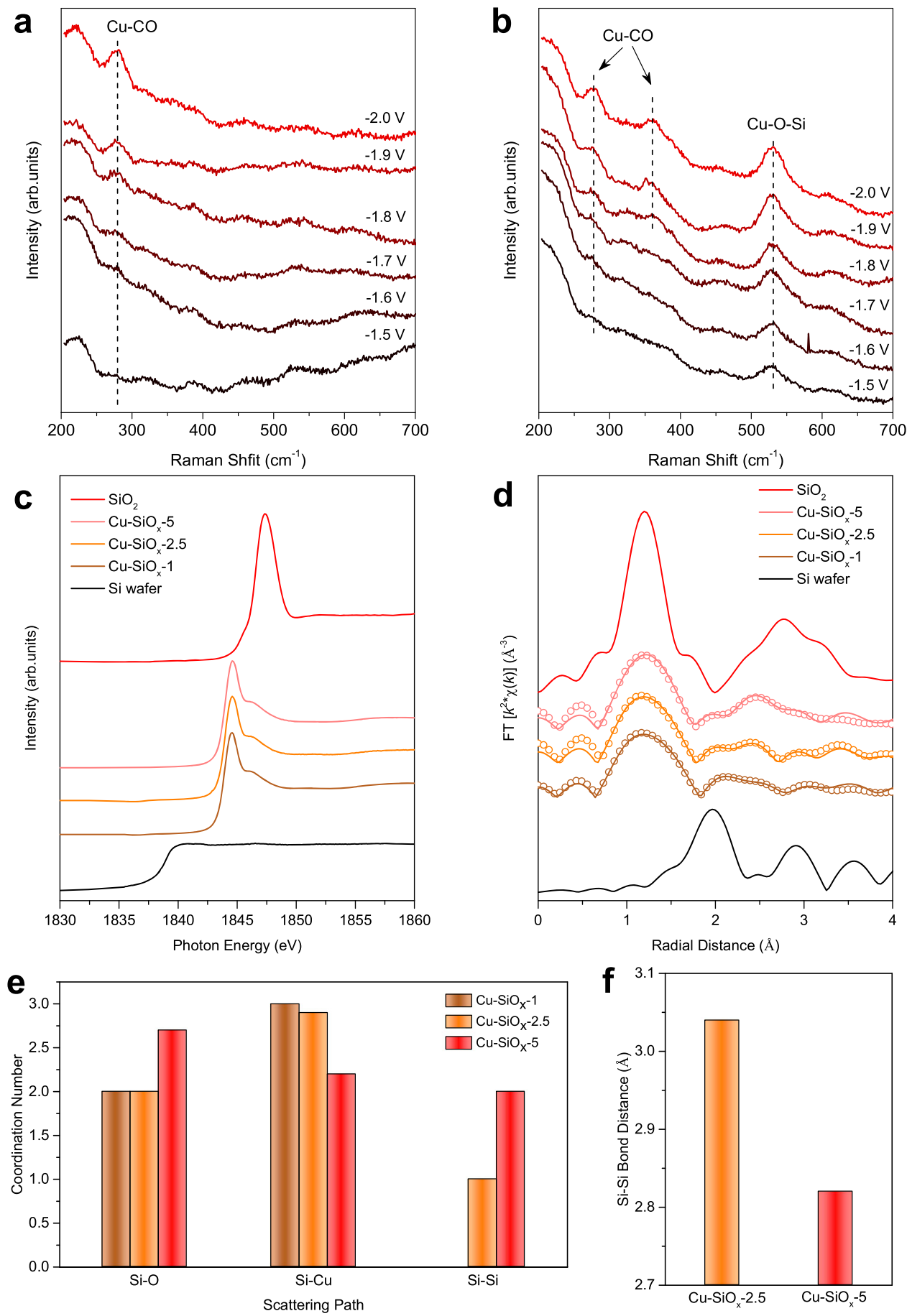

Fig. 4 Spectroscopy studies of the $\mathbf{C u}_{-}$SiO $_{\mathbf{x}}$ catalysts. a, b In-situ Raman spectra of the bare $\mathrm{Cu}(\mathbf{a})$ and $\mathrm{Cu}$-SiOx-2.5 (b) catalysts at a cell potential range of $-1.5 \sim-2.0 \mathrm{~V}$. Current density recorded at each condition is listed in Supplementary Table 4. c Ex-situ Si K-edge XANES spectra of different Cu-SiO ${ }_{x}$ catalysts and the $\mathrm{Si}$ standards (i.e., $\mathrm{Si}$ wafer and $\mathrm{SiO}_{2}$ ). d The $\mathrm{Si}$ K-edge EXAFS spectra (solid lines) and corresponding fitting curves (open circles) of different $\mathrm{Cu}-\mathrm{SiO}_{x}$ catalysts. The $\mathrm{Si}$ K-edge EXAFS spectra of $\mathrm{Si}$ wafer and $\mathrm{SiO}_{2}$ standards are included for comparison. e, $\mathbf{f}$ Simulated coordination number (e) and $\mathrm{Si}-\mathrm{Si}$ bond distance (f) of different $\mathrm{Cu}-\mathrm{SiO}_{x}$ catalysts extracted from their $\mathrm{Si}$ K-edge EXAFS. In-situ Raman analysis was performed during $\mathrm{CO}_{2} \mathrm{RR}_{\text {, }}$ whereas ex-situ Si K-edge XAS was measured upon completion of $\mathrm{CO}_{2} \mathrm{RR}$ at a full-cell potential of $-4.1 \mathrm{~V}$ in $0.1 \mathrm{M} \mathrm{KHCO}_{3}$.

(Supplementary Fig. 36d) ${ }^{34}$. The predominantly metallic $\mathrm{Cu}$ states of the $\mathrm{Cu}-\mathrm{SiO}_{x}$ catalysts revealed by XAS further supports our view that silica clusters are deposited at the surface of $\mathrm{Cu}$ nanoparticles. This finding is also in line with the HAADF-STEM results (Supplementary Fig. 27).

The $\mathrm{Si}$ K-edge XANES of the $\mathrm{Cu}-\mathrm{SiO}_{x}$ catalysts reveals an average +2 oxidation state of the $\mathrm{Si}$ species (Fig. 4c), with absorption onset energy ( $1 \mathrm{~s} \rightarrow 2 p$ transition) and spectral characteristics analogous to the $\mathrm{Si}$ K-edge XANES of the molecular $\mathrm{SiO}$ deposited on highly oriented pyrolytic graphite, reported elsewhere ${ }^{35}$. Increasing the silica loading on $\mathrm{Cu}$ from 1 to $5 \%$ results in an enhancement of the Si K-edge white-line intensity and a blue shift of the absorption onset (Supplementary Fig. 37). A broadening of the white line indicates an overall Si pcharge depletion due to charge redistribution at the $\mathrm{Cu}-\mathrm{SiO}_{x}$ interface with increasing silica loadings, and a positive energy 
shift of Si $1 s$ absorption onset suggests a potential increase of the $\mathrm{Si}$ oxidation state from the charge redistribution process.

The Si K-edge EXAFS of the $\mathrm{Cu}-\mathrm{SiO}_{x}$ catalysts shows a strong peak at $1.3 \AA$, attributable to the $\mathrm{Si}-\mathrm{O}$ bond in the first shell of $\mathrm{Si}$ atoms (Fig. 4d). We fit the Si K-edge EXAFS spectra of different $\mathrm{Cu}-\mathrm{SiO}_{x}$ catalysts with the relevant DFT models having similar silica loadings. We found that the $\mathrm{Si}$ local structures (i.e., coordination number and bond distance) extracted from the EXAFS fitting align well with those obtained from the DFT models (Fig. 4d, Supplementary Fig. 38 and Supplementary Table 5), indicating a general agreement between experimental and computational trends herein. From EXAFS fits, we also found a decrease in the $\mathrm{Si}-\mathrm{Cu}$ coordination from 3 to 2 with the silica loading increasing from 2.5 to $5 \%$ (Fig. 4e), indicating that an increase in the silica loading to $5 \%$ diminishes the interaction between $\mathrm{Cu}$ and silica. Increasing the silica loading from 2.5 to $5 \%$ also results in the growth of silica molecules, evidenced by an increase in the $\mathrm{Si}-\mathrm{O}$ coordination from 2 to 3 , an increase in the $\mathrm{Si}-\mathrm{Si}$ coordination from 1 to 2 , and a $\sim 7 \%$ contraction in the $\mathrm{Si}-\mathrm{Si}$ bond from 3.0 to $2.8 \AA$ (Fig. $4 \mathrm{e}, \mathrm{f}$ ).

Taken together, these results suggest that while $\mathrm{Cu}$ predominantly remains in a metallic state in the $\mathrm{Cu}-\mathrm{SiO}_{x}$ catalyst, the $\mathrm{Si}$ species preserve an oxidation state of $\sim+2$ via $\mathrm{Cu}-\mathrm{O}-\mathrm{Si}$ interaction. An increase in the silica loading from 1 to $2.5 \%$ promotes the formation of stable $\mathrm{Cu}-\mathrm{SiO}_{x}$ interface sites with enhanced $\mathrm{CO}$ coverage to promote $\mathrm{C}-\mathrm{C}$ coupling toward ethylene production, whereas a further increase in the silica loading to $5 \%$ diminishes the $\mathrm{Cu}$ and silica interaction due to the growth of silica molecules, destabilizing the $\mathrm{Cu}-\mathrm{SiO}_{x}$ interface and decreasing the $\mathrm{CO}$ content and therefore ethylene production on the electrode surface.

System performance and catalyst stability. To challenge the versatility of the $\mathrm{Cu}-\mathrm{SiO}_{x}$ catalyst, we assessed $\mathrm{CO}_{2} \mathrm{RR}$ performance using dilute input gas streams with $\mathrm{CO}_{2}$ concentrations in a range typical of flue gas ${ }^{36}$. We tested the $\mathrm{CO}_{2} \mathrm{RR}$ performance of the $\mathrm{Cu}-\mathrm{SiO}_{x}-2.5$ catalyst across a cell potential window of $-3.4 \sim$ $-4.2 \mathrm{~V}$ by co-feeding $\mathrm{CO}_{2}$ and $\mathrm{N}_{2}$ gas feeds with the $\mathrm{CO}_{2}$ concentrations ranging from 10 to $100 \%$. We found that reducing the $\mathrm{CO}_{2}$ concentration induces a slight decrease in current density (Supplementary Fig. 39), due to reduced $\mathrm{CO}_{2}$ availability at the catalyst layer, evidenced by the increasing $\mathrm{H}_{2}$ current densities at reduced $\mathrm{CO}_{2}$ concentrations.

Regulating the $\mathrm{CO}_{2}$ concentration in the full-cell potential window of $-3.6 \sim-4.2 \mathrm{~V}$ results in a high $\mathrm{FE}_{\text {ethylene }}$ of $>50 \%$ with varied $\mathrm{FE}_{\mathrm{CO}}$ and $\mathrm{FE}_{\mathrm{H} 2}$ (Fig. $5 \mathrm{a}-\mathrm{c}$ ). At $-3.6 \mathrm{~V}$, we achieved a $52 \%$ $\mathrm{FE}_{\text {ethylene }}\left(15 \% \mathrm{FE}_{\mathrm{CO}}\right)$ with $10 \% \mathrm{CO}_{2}$ feed, in contrast to a $37 \%$ $\mathrm{FE}_{\text {ethylene }}$ with an increase of $\mathrm{FE}_{\mathrm{CO}}$ to $26 \%$ using $100 \% \mathrm{CO}_{2}$ at similar conditions. The sharp increase of $\mathrm{FE}_{\mathrm{CO}}$ at increasing $\mathrm{CO}_{2}$ concentrations can be attributed to excessive local $\mathrm{CO}_{2}$ in the catalyst layer, blocking active catalyst surface sites for $\mathrm{CO}$ dimerization toward ethylene formation and promoting instead CO production ${ }^{17}$.

Increasing the potential to $-4.2 \mathrm{~V}$ leads to a high $\mathrm{FE}_{\text {ethylene }}$ of $64 \%\left(13 \% \mathrm{FE}_{\mathrm{H} 2}\right)$ with $100 \% \mathrm{CO}_{2}$ feed, whereas the $\mathrm{FE}_{\text {ethylene }}$ decreases to $30 \%$ with a dramatic increase of $\mathrm{FE}_{\mathrm{H} 2}$ to $58 \%$ using $10 \% \mathrm{CO}_{2}$ at the same applied potential. A shift of product selectivity to $\mathrm{H}_{2}$ at low $\mathrm{CO}_{2}$ concentrations and at high negative potentials can be attributed to the $\mathrm{CO}_{2}$ mass transport limitations (Fig. 5c and Supplementary Fig. 39). Taken together, these findings show that $\mathrm{FE}_{\text {ethylene }}$ increases when we constrain $\mathrm{CO}_{2}$ availability, which can be linked to modulation of the surface coverage of ${ }^{*} \mathrm{CO}_{2},{ }^{*} \mathrm{CO}$, and ${ }^{*} \mathrm{H}$ at the catalyst layer ${ }^{17}$. As a result, we achieve a high $\mathrm{FE}_{\text {ethylene }}$ from $\mathrm{CO}_{2} \mathrm{RR}$ by tuning the local $\mathrm{CO}_{2}$ concentration and applied potential/current density. Tuning conditions for high $\mathrm{FE}_{\text {ethylene }}$ and low cell potential, we achieve an $18 \%$ full-cell energy efficiency (EE) toward ethylene production across a broad range of $\mathrm{CO}_{2}$ concentrations, $10-100 \%$ (Fig. 5d).

We also assessed the stability of the $\mathrm{Cu}-\mathrm{SiO}_{x}-2.5$ catalyst at different $\mathrm{CO}_{2}$ concentrations to demonstrate stable selective ethylene electroproduction at industrial-scale reaction rates from various $\mathrm{CO}_{2}$ feedstocks. We performed $\mathrm{CO}_{2} \mathrm{RR}$ at 10,40 and $100 \% \mathrm{CO}_{2}$ concentrations and achieved stable $\mathrm{FE}_{\text {ethylene }}$ of $>60 \%$ at 125,250 , and $300 \mathrm{~mA} \mathrm{~cm}^{-2}$, respectively, over the course of continuous 55-h operation (Fig. 5e and Supplementary Fig. 40). We noted fluctuations in the first $5 \mathrm{~h}$ of stability testing with high $\mathrm{CO}_{2}$ concentrations, a phenomenon we attribute to forming stable cathode:AEM:anode interfaces and stabilizing rates of gas, ion, and water transports with the MEA.

\section{Discussion}

In this work, we show that introducing silica enables $\mathrm{CO}_{2}$ activation and steers the reaction toward ethylene at the $\mathrm{Cu}-\mathrm{SiO}_{x}$ interface, at which silica might act as a dopant to promote $\mathrm{Cu}^{+}$ sites and the formation of $\mathrm{Cu}-\mathrm{Cu}^{+}$interface to assist $\mathrm{C}-\mathrm{C}$ coupling 24,37 . However, in-situ Raman results show only two strong $\mathrm{CO}$ adsorption bands assigned to the metallic $\mathrm{Cu}-\mathrm{CO}$ interactions. Neither any shifts of the $\mathrm{Cu}-\mathrm{CO}$ Raman peaks nor additional Raman peaks related to the $\mathrm{Cu}^{+}-\mathrm{CO}$ adsorption are observed on the $\mathrm{Cu}-\mathrm{SiO}_{x}$ catalyst. These findings suggest that the $\mathrm{Cu}^{+}$sites promoted by silica deposition does not contribute to the $\mathrm{CO}$ adsorption, and the $\mathrm{CO}$ adsorption energetics do not change with and without silica addition, consistent with our DFT calculations (Supplementary Figs. 8-12). We, therefore, conclude that silica, in this case, acts as a structural promoter to assist the electrochemical $\mathrm{CO}_{2}$-to-ethylene conversion at the $\mathrm{Cu}-\mathrm{SiO}_{x}$ catalyst interface.

To demonstrate the universality of our oxide modulation strategy, we theoretically assessed the role of $\mathrm{GeO}_{x}$-an analogous oxide to silica-on the $\mathrm{C}-\mathrm{C}$ coupling reaction at the $\mathrm{Cu}-\mathrm{GeO}_{x}$ interface (Supplementary Figs. 41 and 42). By changing the $\mathrm{GeO}_{x}$ loading ranging from 0 to $5 \%$, we find a similar volcano-shaped dependence of the $\mathrm{OCCOH}^{*}$ formation energy based on the $\mathrm{GeO}_{x}$ loading. The $\mathrm{Cu}$ catalyst with a $\mathrm{GeO}_{x}$ loading up to $\sim 3 \%$ decreases the $\mathrm{OCCOH}^{*}$ formation energy by $\sim-0.6 \mathrm{eV}$ compared to the bare $\mathrm{Cu}$ catalyst, which we attributed to the formation of the $\mathrm{Ge}-\mathrm{O}$ bond between $\mathrm{O}^{\delta-}$ of the $\mathrm{OCCOH}^{*}$ intermediate and $\mathrm{GeO}_{x}$ at the $\mathrm{Cu}-\mathrm{GeO}_{x}$ interface.

In summary, we show an efficient oxide modulation strategy that modifies the activity and intermediate binding characteristics of $\mathrm{Cu}$ catalysts by creating active $\mathrm{Cu}-\mathrm{SiO}_{x}$ surface step sites. The MEA electrolyzer equipped with the $\mathrm{Cu}-\mathrm{SiO}_{x}$ catalyst enables $\mathrm{FE}_{\text {ethylene }}>60 \%$, current densities of up to $300 \mathrm{~mA} \mathrm{~cm}^{-2}$, ethylene full-cell EEs of $18 \%$, and continuous stable operation of $55 \mathrm{~h}$ with a wide range of input $\mathrm{CO}_{2}$ concentrations (10-100\%). With the aid of spectroscopic and electrochemical tools as well as DFT calculations, we reveal that the silica addition can decrease the formation energies of $\mathrm{OCOH}^{*}$ and $\mathrm{OCCOH}^{*}$ by forming strong $\mathrm{Si}-\mathrm{O}$ or $\mathrm{Si}-\mathrm{C}$ bonds at a stable $\mathrm{Cu}-\mathrm{SiO}_{x}$ step site, and thereby accelerate ethylene production. The improved reaction energetics achieved in the oxide-promoted $\mathrm{Cu}$ catalyst would motivate new catalyst design strategies for $\mathrm{CO}_{2} \mathrm{RR}$.

\section{Methods}

DFT calculations. Density functional theory calculations were carried out with the Vienna Ab Initio Simulation Package (VASP) code ${ }^{38,39}$. Perdew-Burke-Ernzerho (PBE) functionals ${ }^{40}$ were used to treat the exchange-correlation interactions, and the projector-augmented wave (PAW) method $^{41}$ was used to solve the ion-electron interactions in the periodic system. All the configurations were first optimized under vacuum calculations and then converged under implicit solvation conditions. Details of DFT calculations were included in Supplementary Note 1. 
a

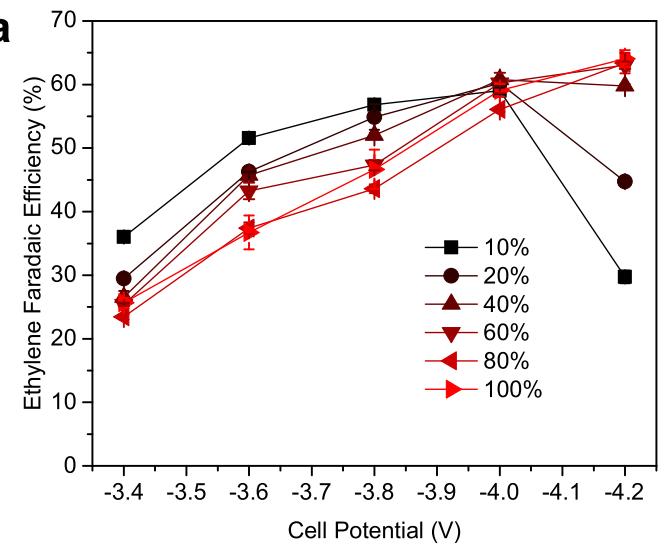

C

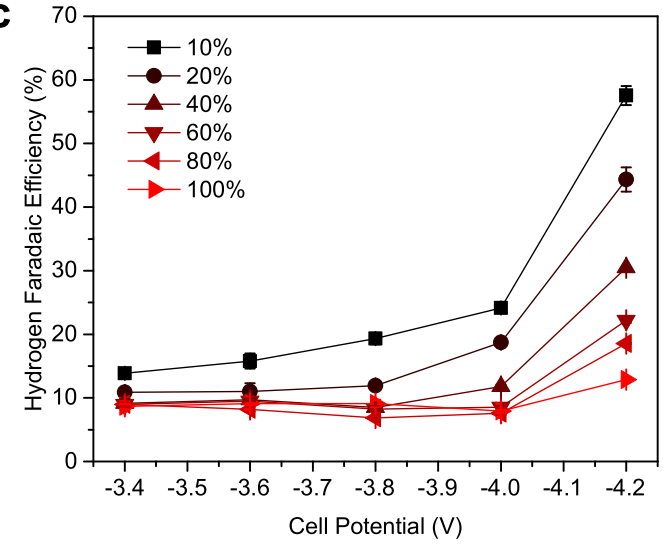

b

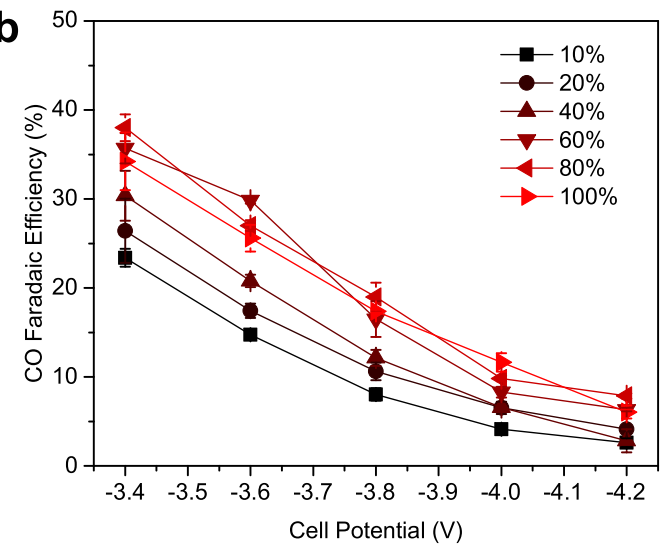

d

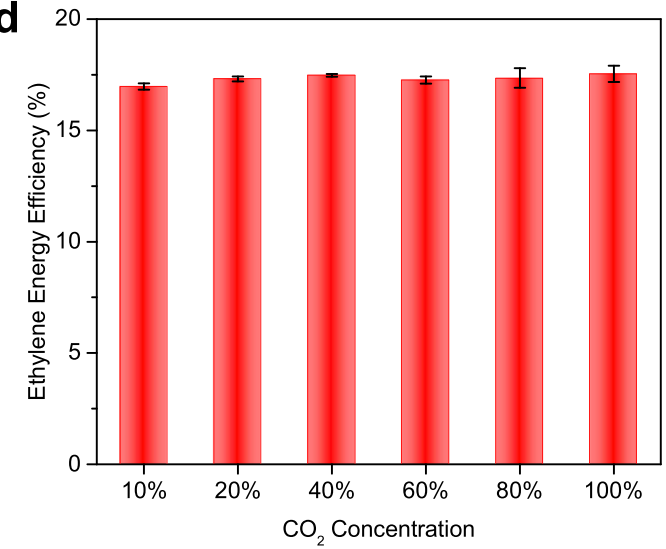

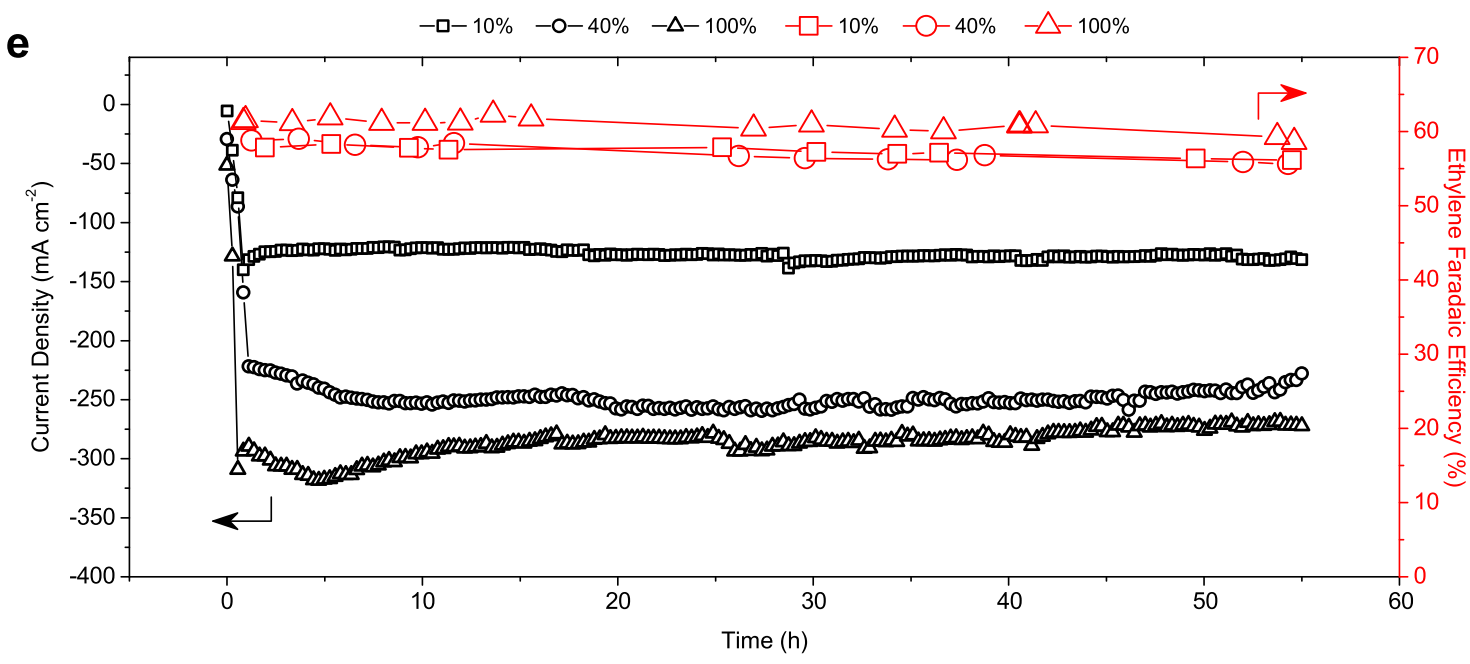

Fig. 5 Applied electrochemical performance of $\mathbf{2 . 5} \%$ silica-loaded $\mathrm{Cu}$ catalyst in a MEA electrolyzer with $\mathbf{0 . 1} \mathbf{M ~ K H C O}_{3}$ anolyte. a-d Effect of $\mathrm{CO}_{2}$ concentration on $\mathrm{FE}_{\text {ethylene }}(\mathbf{a}), \mathrm{FE}_{\mathrm{CO}}(\mathbf{b}), \mathrm{FE}_{\text {hydrogen }}(\mathbf{c})$, and $\mathrm{EE}_{\text {ethylene }}(\mathbf{d})$. Error bars are means $\pm \mathrm{SD}(n=3$ replicates). e Extended operational stability of the MEA equipped with the $\mathrm{Cu}-\mathrm{SiO}_{x}$ under $\mathrm{CO}_{2}$ concentration of $10 \%$ at $-3.8 \mathrm{~V}, 40 \%$ at $-4.0 \mathrm{~V}$, and $100 \%$ at $-4.1 \mathrm{~V}$.

Catalysts preparation. For the synthesis of $2.5 \%$ silica-loaded $\mathrm{Cu}$ catalysts, $0.5984 \mathrm{~g}$ of $\mathrm{CuCl}_{2} .2 \mathrm{H}_{2} \mathrm{O}$ (Sigma-Aldrich, ACS reagent, $\geq 99.0 \%$ ) was dissolved into $180 \mathrm{~mL}$ ethanol under magnetic stirring. Then $90 \mu \mathrm{L}$ of silicon tetrachloride (Sigma-Aldrich, 99.998\% trace metals basis) was injected into the $\mathrm{Cu}(\mathrm{II})$ solutions. Afterward, $0.6 \mathrm{~g}$ of sodium borohydride (Sigma-Aldrich, powder, $\geq 98.0 \%$ ) dispersed in $120 \mathrm{~mL}$ of ethanol was added into the above-mentioned solution under stirring. The color of the solutions changed from blue to darkish. After stirring for $5 \mathrm{~min}$, precipitates formed in the solution were kept for $30 \mathrm{mins}$ and then centrifuged. The as-prepared $\mathrm{Cu}-\mathrm{SiO}_{x}$ precipitates were washed with ethanol under intense ultrasonication at least three times to remove all unreacted reagents. The $\mathrm{Cu}-\mathrm{SiO}_{x}$ catalysts were then dried under vacuum at room temperature overnight. The silica-loaded $\mathrm{Cu}$ catalysts with different $\mathrm{Si} / \mathrm{Cu}$ ratios of $0,0.01$, and 0.05 were synthesized by following a procedure similar to that described above, except for changing the amount of silicon tetrachloride.
Materials characterization. A Hitachi S-5200 SEM/STEM operating at $1 \mathrm{kV}$ was employed to analyze the surface morphology of catalysts. TEM analysis was performed using a Hitachi HF-3300 instrument with an acceleration voltage of 300 $\mathrm{kV}$. An aberration-corrected FEI Titan 80-300 equipped with a CEOS probe and image corrector was used for high-resolution TEM images and EDX. The microscope was operated at an acceleration voltage of $200 \mathrm{kV}$ and STEM micrographs were captured using a HAADF detector (Fischione). The microscope was equipped with four-quadrant windowless silicon drift detectors EDX (Super-X) which increased the angle of collection, and hence, collection efficiency. During EDX mapping, the electron beam used for STEM imaging was rastered over the particles and the characteristic X-rays (resulting from electron-matter interaction) were collected by EDX detectors (four of them available in this microscope). For each EDX map, the area was exposed to the electron beam for 10-15 min, depending on the number of counts collected and the qualitative signal-to-noise ratio. In general, 
once the overall number of counts (detected X-rays) reached $\sim 0.5$ million (depending somewhat on the area size and elements), the maps and the elemental signals were clear. The Agilent 5110 ICP-OES system was employed to determine the elemental composition. P-XRD was performed on a MiniFlex600 instrument with a copper target $(\lambda=1.54056 \AA)$ at room temperature. XPS measurements were carried out on a K-Alpha XPS spectrometer (PHI 5700 ESCA System), using $\mathrm{Al} \mathrm{Ka} \mathrm{X}$-ray radiation $(1486.6 \mathrm{eV})$ for excitation. In-situ XAS measurements at the $\mathrm{Cu}$ K-edge were carried out at the 9BM beamline of Advanced Photon Source (APS, Argonne National Laboratory, Lemont, Illinois, USA) using a home-made flow cell ${ }^{42}$. Ex-situ Si K-edge experiments were conducted at the Soft X-ray Microcharacterization Beamline (SXRMB) of the Canadian Light Source (CLS, Saskatoon, Saskatchewan, Canada) by sealing samples in Kapton tape after the $\mathrm{CO}_{2} \mathrm{RR}$ testing and vacuum drying. Ex-situ XAS measurements at the $\mathrm{Cu} \mathrm{K}$-edge were also recorded at the SXRMB beamline together with ex-situ Si K-edge testing to exclude material oxidation from ex-situ measurements (Supplementary Fig. 43). Fluorescence yield was recorded using silicon drift detectors at both the 9BM and SXRMB beamlines. XANES data were analyzed using Athena software included in a standardized IFEFFIT package ${ }^{43}$. EXAFS fittings were performed using the FEFF software included in the IFEFFIT package ${ }^{44}$. In-situ Raman experiments were performed using a Renishaw inVia Raman microscope in a home-made flow cell (Supplementary Fig. 44) with a water immersion objective. During testing, $\mathrm{CO}_{2}$ with a constant flow rate of 20 s.c.c.m. flowed through the gas compartment, whereas $0.1 \mathrm{M} \mathrm{KHCO}_{3}$ solution with a flow rate of $0.2 \mathrm{~mL} \mathrm{~min}^{-1}$ flowed through the electrolyte compartment. A Pt wire was used as the counter electrode, and a 785-nm laser was used for Raman testing. Signals were recorded using a 5-s integration and averaging ten scans.

Electrode preparation. The cathodes were manufactured via a two-step fabrication procedure. The first step was evaporating $\mathrm{Cu}$ (Kurt J. Lasker Company) on a polytetrafluoroethylene (PTFE) substrate at a constant sputtering rate of $0.45 \mathrm{~A} \mathrm{~s}^{-1}$ at $10^{-6}$ Torr until the sputtering thickness of $150 \mathrm{~nm}$ was achieved. The second step was spray-depositing a homogeneous ink of $\mathrm{Cu}$ catalysts, polymeric binder (Aquivion, D79-25BS), and methanol until the catalyst loading of $1.25 \mathrm{mg} \mathrm{cm}^{-2}$ was achieved. The anodes for the OER were manufactured via a five-step fabrication procedure. The procedure involved (i) etching the titanium (Ti) mesh (Fuel Cell Store) in $5 \mathrm{M} \mathrm{HCl}$ at $70{ }^{\circ} \mathrm{C}$ for $30 \mathrm{~min}$, (ii) preparing a catalyst ink of iridium (III) oxide dehydrate (Alfa Aesar, 99.99\%), 2-propanol and $\mathrm{HCl}$, (iii) immersing the etched Ti mesh into the catalysts ink for $30 \mathrm{~s}$, (iv) drying and sintering the resulting Ti meshes for $15 \mathrm{~min}$ at 100 and $500{ }^{\circ} \mathrm{C}$, respectively, and (v) repeating the immersion, drying, and sintering steps until the total $\mathrm{IrO}_{2}$ loading of $1.5 \mathrm{mg} \mathrm{cm}^{-2}$ was achieved.

$\mathrm{CO}_{2}$ electroreduction. The $\mathrm{CO}_{2} \mathrm{RR}$ performance assessments of the cathode $\mathrm{Cu}-$ $\mathrm{SiO}_{x}$ catalysts were made via a custom-made electrochemical test station. The station was equipped with a potentiostat and booster, $\mathrm{CO}_{2} \mathrm{RR}$ electrolyzer (a membrane electrode assembly electrolyzer purchased from Dioxide Materials), mass flow controller, humidifier, and peristaltic pump.

For $\mathrm{CO}_{2} \mathrm{RR}$ testing, the electrolyzer consisted of anode and cathode flow-field plates with a geometric flow area of $5 \mathrm{~cm}^{2}$. The anode and cathode flow-field plates were made of titanium and stainless steel, respectively, and they were mainly responsible for the distribution of anolyte $\left(0.1 \mathrm{M} \mathrm{KHCO}_{3}\right)$ and reactant $\left(\mathrm{CO}_{2}\right)$ over the surface of the respective electrodes. The anode and cathode electrodes were mounted on their respective flow-field plates and physically isolated from each other by an AEM (Sustainion X37-50 Grade RT). The AEM was activated for at least $24 \mathrm{~h}$ in $1 \mathrm{M} \mathrm{KOH}$ and rinsed with deionized (DI) water continuously for 15 min to remove the $\mathrm{KOH}$ from the surface before the experiments. Upon completion of the electrolyzer assembly, the anolyte $\left(0.1 \mathrm{M} \mathrm{KHCO}_{3}\right)$ and humidified $\mathrm{CO}_{2}$ were supplied to their respective compartments with constant flow rates of $10 \mathrm{~mL} \mathrm{~min}^{-1}$ and 80 s.c.c.m., respectively. The $\mathrm{CO}_{2} \mathrm{RR}$ was then initiated and the corresponding current was recorded. Potentials reported in MEA electrolyzer were non-iR corrected full-cell potentials.

Methods used for quantifying the $\mathrm{CO}_{2} \mathrm{RR}$ products were reported elsewhere ${ }^{45}$. Briefly, a gas chromatography (GC, PerkinElmer Clarus 680), equipped with a Molecular Sieve 5 A capillary column and a packed Carboxen-1000 column, was used to analyze the $\mathrm{CO}_{2} \mathrm{RR}$ gas products. While hydrogen was quantified using a thermal conductivity detector, ethylene was measured using a flame ionization detector, and argon (Linde, 99.999\%) was used as a carrier gas. One-dimensional ${ }^{1} \mathrm{H}$ Nuclear magnetic resonance spectroscopy $\left({ }^{1} \mathrm{H}-\mathrm{NMR}\right)$ coupled with an Agilent DD2 500 spectrometer, was used to evaluate liquid products with Dimethyl sulfoxide (DMSO) diluted in $\mathrm{D}_{2} \mathrm{O}$ as the internal standard. Calculation details of the FEs toward gas and liquid products of $\mathrm{CO}_{2} \mathrm{RR}$ as well as those of the ethylene full-cell EE can be found in Supplementary Note 2. The FE and FE-derived data were obtained by averaging the FEs obtained from three independent experiments, and the data were presented with error bars.

\section{Data availability}

The data that support the findings of this study are available from the corresponding author on reasonable request.
Received: 18 August 2020; Accepted: 29 March 2021; Published online: 14 May 2021

\section{References}

1. Nitopi, S. et al. Progress and perspectives of electrochemical $\mathrm{CO}_{2}$ reduction on copper in aqueous electrolyte. Chem. Rev. 119, 7610-7672 (2019).

2. Jouny, M., Hutchings, G. S. \& Jiao, F. Carbon monoxide electroreduction as an emerging platform for carbon utilization. Nat. Catal. 2, 1062-1070 (2019).

3. Birdja, Y. Y. et al. Advances and challenges in understanding the electrocatalytic conversion of carbon dioxide to fuels. Nat. Energy 4, 732-745 (2019).

4. Jouny, M., Luc, W. \& Jiao, F. General techno-economic analysis of $\mathrm{CO}_{2}$ electrolysis systems. Ind. Eng. Chem. Res. 57, 2165-2177 (2018).

5. Verma, S., Lu, S. \& Kenis, P. J. Co-electrolysis of $\mathrm{CO}_{2}$ and glycerol as a pathway to carbon chemicals with improved technoeconomics due to low electricity consumption. Nat. Energy 4, 466-474 (2019).

6. Cook, R. L., MacDuff, R. C. \& Sammells, A. F. High rate gas phase $\mathrm{CO}_{2}$ reduction to ethylene and methane using gas diffusion electrodes. $J$. Electrochem. Soc. 137, 607-608 (1990).

7. $\mathrm{Ma}, \mathrm{W}$. et al. Electrocatalytic reduction of $\mathrm{CO}_{2}$ to ethylene and ethanol through hydrogen-assisted $\mathrm{C}-\mathrm{C}$ coupling over fluorine-modified copper. Nat. Catal. 3, 478-487 (2020).

8. Verma, S. et al. Insights into the low overpotential electroreduction of $\mathrm{CO}_{2}$ to $\mathrm{CO}$ on a supported gold catalyst in an alkaline flow electrolyzer. ACS Energy Lett. 3, 193-198 (2017).

9. Huang, J. et al. Potential-induced nanoclustering of metallic catalysts during electrochemical $\mathrm{CO}_{2}$ reduction. Nat. Commun. 9, 3117 (2018).

10. Gabardo, C. M. et al. Continuous carbon dioxide electroreduction to concentrated multi-carbon products using a membrane electrode assembly. Joule 3, 2777-2791 (2019).

11. Ripatti, D. S., Veltman, T. R. \& Kanan, M. W. Carbon monoxide gas diffusion electrolysis that produces concentrated $\mathrm{C}_{2}$ products with high single-pass conversion. Joule 3, 240-256 (2019).

12. Ren, $\mathrm{S}$. et al. Molecular electrocatalysts can mediate fast, selective $\mathrm{CO}_{2}$ reduction in a flow cell. Science 365, 367-369 (2019).

13. $\mathrm{Li}, \mathrm{T}$. et al. Electrolytic conversion of bicarbonate into $\mathrm{CO}$ in a flow cell. Joule 3, 1487-1497 (2019).

14. Lee, $\mathrm{G}$. et al. Electrochemical upgrade of $\mathrm{CO}_{2}$ from amine capture solution. Nat. Energy 6, 46-53 (2021)

15. Cheng, T., Xiao, H. \& Goddard, W. A. Nature of the active sites for CO reduction on copper nanoparticles; suggestions for optimizing performance. J. Am. Chem. Soc. 139, 11642-11645 (2017)

16. Vasileff, A., Xu, C., Jiao, Y., Zheng, Y. \& Qiao, S. Z. Surface and interface engineering in copper-based bimetallic materials for selective $\mathrm{CO}_{2}$ electroreduction. CHEM 4, 1809-1831 (2018).

17. Tan, Y. C., Lee, K. B., Song, H. \& Oh, J. Modulating local $\mathrm{CO}_{2}$ concentration as a general strategy for enhancing $\mathrm{C}-\mathrm{C}$ coupling in $\mathrm{CO}_{2}$ electroreduction. Joule 4, 1104-1120 (2020).

18. Arán-Ais, R. M., Scholten, F., Kunze, S., Rizo, R. \& Roldan Cuenya, B. The role of in situ generated morphological motifs and $\mathrm{Cu}(\mathrm{I})$ species in $\mathrm{C}_{2+}$ product selectivity during $\mathrm{CO}_{2}$ pulsed electroreduction. Nat. Energy 5, 317-325 (2020)

19. Mistry, H. et al. Highly selective plasma-activated copper catalysts for carbon dioxide reduction to ethylene. Nat. Commun. 7, 12123 (2016).

20. Hoang, T. T. et al. Nanoporous copper-silver alloys by additive-controlled electrodeposition for the selective electroreduction of $\mathrm{CO}_{2}$ to ethylene and ethanol. J. Am. Chem. Soc. 140, 5791-5797 (2018).

21. Gao, J. et al. Selective C-C coupling in carbon dioxide electroreduction via efficient spillover of intermediates as supported by operando Raman spectroscopy. J. Am. Chem. Soc. 141, 18704-18714 (2019).

22. Li, F. et al. Molecular tuning of $\mathrm{CO}_{2}$-to-ethylene conversion. Nature 577, 509-513 (2020).

23. Thevenon, A., Rosas-Hernández, A., Peters, J. C. \& Agapie, T. In-situ nanostructuring and stabilization of polycrystalline copper by an organic salt additive promotes electrocatalytic $\mathrm{CO}_{2}$ reduction to ethylene. Angew. Chem Int. Ed. 58, 16952-16958 (2019).

24. Xiao, H., Goddard, W. A., Cheng, T. \& Liu, Y. Cu metal embedded in oxidized matrix catalyst to promote $\mathrm{CO}_{2}$ activation and $\mathrm{CO}$ dimerization for electrochemical reduction of $\mathrm{CO}_{2}$. Proc. Natl Acad. Sci. USA 114, 6685-6688 (2017).

25. Pérez-Gallent, E., Figueiredo, M. C., Calle-Vallejo, F. \& Koper, M. T. Spectroscopic observation of a hydrogenated CO dimer intermediate during $\mathrm{CO}$ reduction on $\mathrm{Cu}(100)$ electrodes. Angew. Chem. Int. Ed. 129, 3675-3678 (2017).

26. Qian, C. et al. Catalytic $\mathrm{CO}_{2}$ reduction by palladium-decorated silicon-hydride nanosheets. Nat. Catal. 2, 46-54 (2019). 
27. Sun, W. et al. Heterogeneous reduction of carbon dioxide by hydrideterminated silicon nanocrystals. Nat. Commun. 7, 12553 (2016).

28. Goyal, P., Purdue, M. J. \& Farooq, S. Adsorption and diffusion of $\mathrm{N}_{2}$ and $\mathrm{CO}_{2}$ and their mixture on silica gel. Ind. Eng. Chem. Res. 58, 19611-19622 (2019).

29. $\mathrm{Xu}, \mathrm{C}$. et al. Interfacing with silica boosts the catalysis of copper. Nat. Commun. 9, 3367 (2018).

30. Taylor, J. A., Lancaster, G. M., Ignatiev, A. \& Rabalais, J. W. Interactions of ion beams with surfaces. Reactions of nitrogen with silicon and its oxides. J. Chem. Phys. 68, 1776-1784 (1978).

31. Ren, D., Ang, B. S.-H. \& Yeo, B. S. Tuning the selectivity of carbon dioxide electroreduction toward ethanol on oxide-derived $\mathrm{Cu}_{\mathrm{x}} \mathrm{Zn}$ catalysts. ACS Catal. 6, 8239-8247 (2016).

32. Akemann, W. \& Otto, A. The effect of atomic scale surface disorder on bonding and activation of adsorbates: vibrational properties of $\mathrm{CO}$ and $\mathrm{CO}$, on copper. Surf. Sci. 287-288, 104-109 (1993).

33. Chen, $\mathrm{X}$. et al. Electrochemical $\mathrm{CO}_{2}$-to-ethylene conversion on polyamineincorporated $\mathrm{Cu}$ electrodes. Nat. Catal. 4, 20-27 (2020).

34. Varandili, S. B. et al. Synthesis of $\mathrm{Cu} / \mathrm{CeO}_{2-\mathrm{x}}$ nanocrystalline heterodimers with interfacial active sites to promote $\mathrm{CO}_{2}$ electroreduction. ACS Catal. 9, 5035-5046 (2019).

35. Baba, Y., Sekiguchi, T., Shimoyama, I. \& Hirao, N. Electronic structures of silicon monoxide film probed by X-ray absorption spectroscopy. Surf. Sci. 612, 77-81 (2013).

36. $\mathrm{Xu}, \mathrm{Y}$. et al. Oxygen-tolerant electroproduction of $\mathrm{C}_{2}$ products from simulated flue gas. Energy Environ. Sci. 13, 554-561 (2020).

37. Gong, J. et al. Synthesis of ethanol via syngas on $\mathrm{Cu} / \mathrm{SiO}_{2}$ catalysts with balanced $\mathrm{Cu}^{0}-\mathrm{Cu}^{+}$sites. J. Am. Chem. Soc. 134, 13922-13925 (2012).

38. Kresse, G. \& Hafner, J. Ab initio molecular dynamics for liquid metals. Phys. Rev. B 47, 558-561 (1993).

39. Kresse, G. \& Furthmüller, J. Efficiency of ab-initio total energy calculations for metals and semiconductors using a plane-wave basis set. Comput. Mater. Sci. 6, 15-50 (1996).

40. Perdew, J. P., Burke, K. \& Ernzerhof, M. Generalized gradient approximation made simple. Phys. Rev. Lett. 77, 3865-3868 (1996).

41. Payne, M. C., Teter, M. P., Allan, D. C., Arias, T. \& Joannopoulos, A. J. Iterative minimization techniques for ab initio total-energy calculations: molecular dynamics and conjugate gradients. Rev. Mod. Phys. 64, 1045-1097 (1992).

42. Li, J. et al. Copper adparticle enabled selective electrosynthesis of $n$-propanol. Nat. Commun. 9, 4614 (2018).

43. Ravel, B. \& Newville, M. Athena, Artemis, Hephaestus: data analysis for X-ray absorption spectroscopy using IFEFFIT. J. Synchrotron Radiat. 12, 537-541 (2005).

44. $\mathrm{Li}$, J. et al. Revealing the synergy of mono/bimetallic $\mathrm{PdPt} / \mathrm{TiO}_{2}$ heterostructure for enhanced photoresponse performance. J. Phys. Chem. C 121, 24861-24870 (2017)

45. Li, J. et al. Enhanced multi-carbon alcohol electroproduction from $\mathrm{CO}$ via modulated hydrogen adsorption. Nat. Commun. 11, 3685 (2020).

\section{Acknowledgements}

This work has received financial support from the Ontario Research Fund ResearchExcellence Program, the Natural Sciences and Engineering Research Council (NSERC) of Canada, the CIFAR Bio-Inspired Solar Energy Program, and the University of Toronto Connaught grant. This research used synchrotron resources of the Advanced Photon Source (APS), an Office of Science User Facility operated for the U.S. Department of Energy (DOE) Office of Science by Argonne National Laboratory, and was supported by the U.S. DOE under Contract No. DE-AC02-06CH11357, and the Canadian Light Source and its funding partners. This research also used infrastructure provided by the Canada Foundation for Innovation and the Ontario Research Fund. We thank Dr. T.P. Wu, Dr. Y.Z. Finfrock and Dr. L. Ma for technical support at 9BM beamline of APS. D.S. acknowledges the NSERC E.W.R Steacie Memorial Fellowship. J.L. acknowledges the Banting Postdoctoral Fellowships program. DFT calculations were performed on the Massachusetts Green High Performance Computing Center (MGHPCC). The authors also acknowledge the Texas Advanced Computing Center (TACC) at the University of Texas at Austin for partially providing HPC resources that have contributed to the research results reported within this paper. Our thanks also goes to institutional faculty start-up funds from University of Massachusetts Lowell.

\section{Author contributions}

E.H.S. and D.S. supervised the project. J.L. and A.O. conceived the idea, carried out all the experiments, and wrote the manuscript. F.C. supervised and M.W. performed the DFT simulations and both wrote the corresponding sections. Z.Y.W. assisted the DFT discussion. J.L. and Y.F.H. performed and analyzed synchrotron data. A.O. and J.L. performed the in-situ Raman measurements. Y.H.W., R.Z., D.R., and B.C assisted in SEM and TEM analysis. D.-H.N. and J.W. conducted XRD and XPS measurements. F.W.L., Y.X., X.W., M.C.L., and M.G. assisted in electrochemical experiments and analysis. All authors discussed the results and assisted during manuscript preparation.

\section{Competing interests}

The authors declare no competing interests.

\section{Additional information}

Supplementary information The online version contains supplementary material available at https://doi.org/10.1038/s41467-021-23023-0.

Correspondence and requests for materials should be addressed to F.C., E.H.S. or D.S.

Peer review information Nature Communications thanks the anonymous reviewer(s) for their contribution to the peer review of this work. Peer reviewer reports are available.

Reprints and permission information is available at http://www.nature.com/reprints

Publisher's note Springer Nature remains neutral with regard to jurisdictional claims in published maps and institutional affiliations.

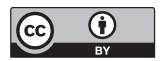

Open Access This article is licensed under a Creative Commons Attribution 4.0 International License, which permits use, sharing, adaptation, distribution and reproduction in any medium or format, as long as you give appropriate credit to the original author(s) and the source, provide a link to the Creative Commons license, and indicate if changes were made. The images or other third party material in this article are included in the article's Creative Commons license, unless indicated otherwise in a credit line to the material. If material is not included in the article's Creative Commons license and your intended use is not permitted by statutory regulation or exceeds the permitted use, you will need to obtain permission directly from the copyright holder. To view a copy of this license, visit http://creativecommons.org/ licenses/by/4.0/.

(c) The Author(s) 2021 